\title{
Synthesis and Antimicrobial Activities of Some New Thieno and Furopyrimidine Derivatives
}

\author{
M. I. Hossain ${ }^{1}$, M. M. H. Bhuiyan \\ Department of Chemistry, University of Chittagong, Chittagong-4331, Bangladesh \\ Received 6 January 2009, accepted in final revised form 14 April 2009
}

\begin{abstract}
Fused pyrimidines, 8,9-dimethyl[1,2,4]triazolo[4,3-c]thieno[3,2-e]pyrimidine $\mathbf{5}, \quad 3,8,9$ trimethyl[1,2,4]triazolo[4,3-c]thieno[3,2-e]pyrimidine 6, 4-benzylidinehydrazono-5,6 dimethylthieno[2,3-d]pyrimidine 7, 4-[4'-hydroxybenzylidine]hydrazono-5,6-dimethylthieno[2,3-d]pyrimidine 8, 4-[4'-tolylidin]hydrazono-5,6-dimethylthieno[2,3-d]pyrimidine 9, 4-[4'-nitrobenzylidine]hydrazono-5-ethyl-6-methylthieno[2,3-d]pyrimidine $\mathbf{1 0}$ and 4-[4'chlorobenzylidine]hydrazono-5-ethyl-6-methylthieno[2,3-d]pyrimidine $\mathbf{1 1}$ are prepared in good yield by an initial treatment of 2-amino-4,5-dimethylthiophene-3-carbonitrile 1 with formic acid, affording 5,6-dimethylthieno[2,3-d]pyrimidin-4(3H)-one $\mathbf{2}$, which is chlorinated with thionyl chloride and then hydrazinated with hydrazine hydrate. Finally hydrazino compound $\mathbf{4}$ is reacted with formic acid, acetic anhydrate, benzaldehyde, phydroxybenzaldehyde, p-toluayldehyde, p-nitrobenzaldehyde and p-chlorobenzaldehyde to give thienotriazolopyrimidines 5-6 and thienopyrimidines 7-11 respectively. All the compounds have been screened for their antimicrobial activity.
\end{abstract}

Keywords: Fused pyrimidines; Hydrazino compound; Thienotriazolopyrmidines; Thienopyrimidines; Antimicrobial activity.

(C) 2009 JSR Publications. ISSN: 2070-0237 (Print); 2070-0245 (Online). All rights reserved.

DOI: 10.3329/jsr.v1i2.2299

\section{Introduction}

The formation of novel fused heterocycles is an important task for heterocyclic chemists from various points of view for the development of living things. Further more, many condensed heterocyclic systems, especially when linked to a pyrimidine ring as thienopyrimidine play an important role as potent analgesic [1], anti-inflammatory [1-5], antipyretic [6-8], antimicrobial [9-10], anticonvulsant [11], fungicidal [12], antiplatelet activities [13-15], and other central nervous system (CNS) affecting activities [16]. In addition, pyrimidine nucleus can be found in a broad variety of antibacterial, anticancer and anti-tumor agents as well as in agrochemicals and veterinary products [17-18]. In continuation of our interest in the development of new and simple methods for the synthesis of polyfunctional substituted heterocycles, furopyrimidines and thieno-

\footnotetext{
${ }^{1}$ Corresponding author: ismailcu@gmail.com
} 
pyrimidines, with anticipated biological activity [19-27], the present work describes the syntheses and antimicrobial activities of some furopyrimidines and thienopyrimidnes.

\section{Materials and Methods}

\subsection{Physical measurements}

Melting points were recorded with Electrothermal melting point apparatus and are uncorrected. Evaporation of solvents were performed under reduced pressure on a Buchi rotary evaporator. Thin layer chromatography was performed on Kieselgel $\mathrm{GF}_{254}$ and visualization was accomplished by Iodine Flask or UV Lamp. Column chromatography was carried out with silica gel $\mathrm{G}_{60}\left(100-200\right.$ mesh). ${ }^{1} \mathrm{H}-\mathrm{NMR}(400 \mathrm{MHz})$ and ${ }^{13} \mathrm{C}-\mathrm{NMR}$ (400 MHz) spectra were recorded for solutions in deuterio chloroform $\mathrm{CDCl}_{3}$, deuterio methanol $\mathrm{CD}_{3} \mathrm{OD}$ and deuterio dimethylsulphoxide (DMSO- $\left.\mathrm{d}_{6}\right)\left(\mathrm{CD}_{3}\right)_{2} \mathrm{SO}$ as solvent. Chemical shifts were reported in $\delta$ unit (ppm) with reference to TMS as an internal standard. The substrate $o$-aminonitrile, 2-amino-4,5-dimethylthiophene-3-carbonitrile 1 was prepared from 2-butanone by reacting with malononitrile and sulphur according to literature procedure [28].

Synthesis of 5,6-dimethylthieno[2,3-d]pyrimidin-4(3H)-one (2):

A solution of $o$-aminonitrile 1 (2.0 g, $13.15 \mathrm{mmol})$ and formic acid (2 ml) was refluxed for 3 hours at $100^{\circ} \mathrm{C}$ with continuous stirring. The progress of the reaction was monitored by TLC (ethylacetate: $n$-hexane, $1: 4, v / v, R_{f}=0.39$ ) on silica gel and showed complete conversion of the reactant to the product. After completing the reaction, the mixture was cooled to room temperature and ethanol was added whereby a yellow precipitate was obtained. The precipitate was collected by filtration and recrystallized from ethanol to afford thienopyrimidinone 2 (2.05 g, $85 \%$ ) as yellowish crystals, m.p. $136-138^{\circ} \mathrm{C} .{ }^{1} \mathrm{H}-$ NMR (DMSO-d ${ }_{6}$ ): $\delta_{H} 2.14$ (s, 6H, 2×CH ), 7.60 (s, 1H, CH), 9.60 (s, 1H, NH).

Synthesis of 4-chloro-5,6-dimethylthieno[2,3-d]pyrimidine (3):

A mixture of pyrimidinone 2 (2.05 g, $11.5 \mathrm{mmol})$ and thionyl chloride (20 ml) was refluxed for 2 hours at $90^{\circ} \mathrm{C}$ bath temperature with stirring. After the completion of the reaction, the mixture was standing to cool. Then the mixture was poured onto ice-water and stirred for another 30 minutes. The precipitate was collected by filtration and recrystallized from ethanol to give chloropyrimidine $3(1.44 \mathrm{~g}, 63.88 \%)$ as yellow crystals, m.p. $150-155^{\circ} \mathrm{C} .{ }^{1} \mathrm{H}-\mathrm{NMR}$ (DMSO-d 6 ): $\delta_{\mathrm{H}} 2.14$ (s, $6 \mathrm{H}, 2 \times \mathrm{CH}_{3}$ ), 7.60 (s, $1 \mathrm{H}, \mathrm{CH}$ ).

Synthesis of 4-hydrazino-5,6-dimethylthieno[2,3-d]pyrimidine (4):

A mixture of chloro compound 3 (1.44g, $7.28 \mathrm{mmol})$ and hydrazine hydrate $(8 \mathrm{ml})$ in dioxane $(20 \mathrm{ml})$ was refluxed at $120^{\circ} \mathrm{C}$ for one hour whereby a solid was separated. It was then filtered and recrystallized from dioxane to afford hydrazinopyrimidine 4 (1.01g, $78 \%$ ) as yellowish crystals, m.p. $161-163^{\circ} \mathrm{C} .{ }^{1} \mathrm{H}-\mathrm{NMR}\left(\mathrm{DMSO}_{6} \mathrm{~d}_{6}\right): \delta_{\mathrm{H}} 2.14$ (s, 6H, $\left.2 \times \mathrm{CH}_{3}\right), 3.60(\mathrm{~s}, 1 \mathrm{H}, \mathrm{NH}), 4.10\left(\mathrm{~s}, 2 \mathrm{H},-\mathrm{NH}_{2}\right), 8.10(\mathrm{~s}, 1 \mathrm{H}, \mathrm{CH})$. 
Synthesis of 8,9-dimethyl[1,2,4] triazolo[4,3-c] thieno[3,2-e]pyrimidine (5):

An equimolar amount of hydrazino compound 4 (0.89g, $5 \mathrm{mmol})$ and formic acid (5 $\mathrm{mmol})$ in dioxane $(20 \mathrm{ml})$ was refluxed at $120^{\circ} \mathrm{C}$ for about 3 hours with continuous stirring. The reaction mixture was then concentrated and left to cool overnight to room temperature for complete precipitation. The obtained solid was then filtered off, dried and recrystallized from ethanol to give compound $5(0.87 \mathrm{~g}, 85.2 \%)$ as brown crystals, m.p. 140-142 ${ }^{\circ} \mathrm{C} .{ }^{1} \mathrm{H}-\mathrm{NMR}\left(\mathrm{DMSO}_{6}\right.$ ): $\delta_{\mathrm{H}} 2.14$ (s, 6H, $2 \times \mathrm{CH}_{3}$ ), 7.90 (s, 1H, 5-CH), 8.50 (s, 1H, 3-CH). ${ }^{13} \mathrm{C}-\mathrm{NMR}$ (DMSO-d 6 ): $\delta_{\mathrm{C}} 158.0$ (C-5), 147.9 (C-3), 135.8 (C-9), 135.1 (C-8), 129.2 (C-9a), 123.9 (C-6a), 8.0, 5.6.

Synthesis of 3,8,9-trimethyl[1,2,4] triazolo[4,3-c] thieno[3,2-e]pyrimidine (6):

An equimolar amount of hydrazino compound 4 (0.89g, $5 \mathrm{mmol})$ and acetic anhydrate (5 mmol) in methanol $(20 \mathrm{ml})$ was refluxed at $65^{\circ} \mathrm{C}$ for about 2 hours with continuous stirring. The reaction mixture was then concentrated and left to cool overnight to room temperature for complete precipitation. The separated solid was then filtered off, dried and recrystallized from methanol to give compound $6(0.71 \mathrm{~g}, 65.4 \%)$ as brown crystals, m.p.

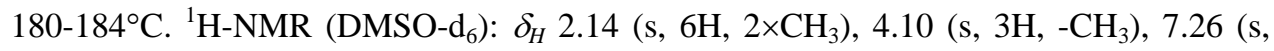
$1 \mathrm{H}, \mathrm{CH}) .{ }^{13} \mathrm{C}-\mathrm{NMR}$ (DMSO-d $\left.{ }_{6}\right): \delta_{\mathrm{C}} 160.4$ (C-3), 158.0 (C-5), 147.6 (C-9b), 135.8 (C-9), 135.1 (C-8), 129.2 (C-9a), 123.9 (C-6a), 11.6, 8.0, 5.6.

General procedure for the synthesis of hydrazonothienopyrimidine (7-11):

An equimolar amount of hydrazino compound 4 (0.89g, $5 \mathrm{mmol})$ and different aldehydes (5 mmol) one by one i.e., benzaldehyde, $p$-hydroxybenzaldehyde, $p$-tolualdehyde, $p$ nitrobenzaldehyde and $p$-chlorobenzaldehyde in ethanol $(20 \mathrm{ml})$ was refluxed at $80^{\circ} \mathrm{C}$ for about 2-3 hours with continuous stirring. The reaction mixture was then concentrated and left to cool overnight to room temperature for complete precipitation. The precipitated solid was then filtered off, dried and recrystallized from ethanol to give hydrazonothienopyrimidines 7-11.

4-benzylidinehydrazono-5,6-dimethylthieno[2,3-d]pyrimidine (7):

Yield: $0.72 \mathrm{~g}$ (51.2\%), white crystals, m.p. $170-173^{\circ} \mathrm{C}$.

${ }^{1} \mathrm{H}-\mathrm{NMR}\left(\mathrm{DMSO}-\mathrm{d}_{6}\right.$ ): $\delta_{\mathrm{H}} 2.14$ (s, 6H, 2×CH ), 1.61 (s, 1H, NH), 7.40 (m, 5H, -Ph), 7.80 (s, $1 \mathrm{H}, 2-\mathrm{CH}), 8.60$ (s, $1 \mathrm{H}, \mathrm{CH})$.

${ }^{13} \mathrm{C}-\mathrm{NMR}$ (DMSO-d 6 ): $\delta_{\mathrm{C}} 167.7$ (C-4), 157.1 (C-2), 154.7 (benzylic carbon), 136.1 (C-5), 135.1 (C-6), 130.8, 129.2, 128.8 (benzene ring carbon), 123.9, 7.7, 5.8.

4-[4'-hydroxybenzylidine]hydrazono-5,6-dimethylthieno[2,3-d]pyrimidine (8):

Yield: 1.10g (73.5\%), yellowish crystals, m.p. $117-121^{\circ} \mathrm{C}$. 
${ }^{1} \mathrm{H}-\mathrm{NMR}\left(\mathrm{DMSO}-\mathrm{d}_{6}\right.$ ): $\delta_{\mathrm{H}} 2.18$ (s, 6H, $2 \times \mathrm{CH}_{3}$ ), 1.78 (s, $\left.1 \mathrm{H}, \mathrm{NH}\right), 6.62$ (s, 1H, 2-CH), 7.47.6 (dd, 4H, -Ph), 7.70 (s, 1H, CH), 8.10 (s, 1H, -OH).

${ }^{13} \mathrm{C}-\mathrm{NMR}$ (DMSO-d $\mathrm{d}_{6}$ ): $\delta_{\mathrm{C}} 167.7$ (C-4), 159.6 (C-4), 157.1 (C-2), 154.7 (benzylic carbon), 135.8 (C-5), 135.1 (C-6), 123.9-123.1 (benzene ring carbon), 7.7, 5.8.

4-[4'-tolylidin] hydrazono-5,6-dimethylthieno[2,3-d]pyrimidine (9):

Yield: 0.98g (67.0\%), brown crystals, m.p. $192-194^{\circ} \mathrm{C}$.

${ }^{1} \mathrm{H}-\mathrm{NMR}\left(\mathrm{DMSO}-\mathrm{d}_{6}\right.$ ): $\delta_{\mathrm{H}} 1.14$ (s, 6H, 2×CH ), 2.40 (s, 3H, $\mathrm{CH}_{3}$ ), 7.20 (s, 1H, NH), 7.78.1 (dd, 4H, -Ph), 8.70 (s, 1H, 2-CH), 9.90 (s, 1H, CH).

${ }^{13} \mathrm{C}-\mathrm{NMR}$ (DMSO-d $\mathrm{d}_{6}$ ): $\delta_{\mathrm{C}} 167.7$ (C-4), 157.1 (C-2), 154.7 (benzylic carbon), $140.0\left(\mathrm{C}-4^{\prime}\right)$, 135.8 (C-5), 135.1 (C-4), 129.1 (benzene ring carbon), 20.9, 7.7, 5.8.

4-[4'-nitrobenzylidine] hydrazono-5-ethyl-6-methylthieno[2,3-d]pyrimidine (10):

Yield: $0.85 \mathrm{~g}$ (52.2\%), brown crystals, m.p. $175-180^{\circ} \mathrm{C}$.

${ }^{1} \mathrm{H}-\mathrm{NMR}\left(\mathrm{DMSO}-\mathrm{d}_{6}\right.$ ): $\delta_{\mathrm{H}} 1.20$ (s, 6H, $2 \times \mathrm{CH}_{3}$ ), 2.20 (s, $1 \mathrm{H}, \mathrm{NH}$ ), 7.30 (s, 1H, 2-CH), 7.47.9 (dd, 4H, -Ph), 8.70 (s, 1H, CH).

${ }^{13}$ C-NMR (DMSO-d $\mathrm{d}_{6}$ ): $\delta_{\mathrm{C}} 167.7$ (C-4), 157.1 (C-2), 154.7 (benzylic carbon), $150.7\left(\mathrm{C}-4^{\prime}\right.$ ), 137.3, 135.8, 135.1, 129.2, 126.8 (benzene ring carbon), 123.9, 7.7, 5.8.

4-[4'-chlorobenzylidine] hydrazono-5-ethyl-6-methylthieno[2,3-d]pyrimidine (11):

Yield: $1.14 \mathrm{~g}$ (72.5\%), yellowish crystals, m.p. $182-183^{\circ} \mathrm{C}$.

${ }^{1} \mathrm{H}-\mathrm{NMR}\left(\mathrm{DMSO}-\mathrm{d}_{6}\right.$ ): $\delta_{\mathrm{H}} 1.14$ (s, 6H, $2 \times \mathrm{CH}_{3}$ ), 2.20 (s, 1H, NH), 6.80 (s, 1H, 2-CH), 7.37.8 (dd, 4H, -Ph), 8.80 (s, 1H, CH).

${ }^{13} \mathrm{C}-\mathrm{NMR}$ (DMSO-d $\mathrm{d}_{6}$ ): $\delta_{\mathrm{C}} 167.7$ (C-4), 157.1 (C-2), 154.7 (benzylic carbon), 136.1 (C'-4), 135.8, 135.1, 129.7-129.2 (benzene ring carbon), 123.9, 7.7, 5.8 .

\subsection{Antibacterial and Antifungal Screenings}

All the synthesized compounds (2-11) were screened for their antibacterial activity against three gram-positive bacteria Bacillus cereus (BTCC 19), Bacillus subtilis and Staphylococcus aureus and three Gram-negative bacteria Shigella dysenteriae (AE 14396), Salmonela typhi (AE 14612) and Pseudomonous sp. (Tables 1 and 2). The antifungal activity was tested against the fungi Macrophomina phaseolina (Tassi) Goid, Fusarium equiseti (Corda) Sacc, Alternaria alternata (Fr.) Kedissler, Colletotrichum corchori Ikata (Yoshida) and Curvularia lunata (see Table 3). For the screening of antibacterial activities, the disc diffusion method [31] was used with solvent methanol. For antifungal test, the poisoned-food technique [32] was frequently used by the solvent methanol. The tested compounds were dissolved in methanol to get a solution of 
$1 \mathrm{mg} \mathrm{mL}^{-1}$. The inhibition zones were measured in millimeters at the end of an incubation period of 48 hours at $(35 \pm 2)^{\circ} \mathrm{C}$. Methanol alone showed no inhibition. Commercial antibacterial and antifungal brands, respectively, Ampicillin and Nystatin were also tested under similar conditions for comparison. Nutrient agar (NA) and potato dextrose agar (PDA) were used as basal media to test bacteria and fungi respectively.

Table 1. Antibacterial screenings (gram positive) of the test compounds.

\begin{tabular}{cccc}
\hline \multirow{2}{*}{ Compound No. } & \multicolumn{3}{c}{ Diameter of zone of inhibition in mm $(100 \mu \mathrm{g}(\mathrm{dw}) / \mathrm{disc})$} \\
\cline { 2 - 4 } & $\begin{array}{c}\text { Bacillus } \\
\text { Subtilis }\end{array}$ & $\begin{array}{c}\text { Staphylococcus } \\
\text { Aureus }\end{array}$ & $\begin{array}{c}\text { Bacillus } \\
\text { Cereus }\end{array}$ \\
\hline $\mathbf{2}$ & 8 & - & - \\
$\mathbf{3}$ & - & 5 & 9 \\
$\mathbf{4}$ & 13 & 8 & 13 \\
$\mathbf{5}$ & $31^{*}$ & $25^{*}$ & 18 \\
$\mathbf{6}$ & $28^{*}$ & $21^{*}$ & $24^{*}$ \\
$\mathbf{7}$ & 11 & 16 & 17 \\
$\mathbf{8}$ & 19 & 11 & 16 \\
$\mathbf{9}$ & 17 & 9 & 12 \\
$\mathbf{1 0}$ & 19 & $22^{*}$ & 17 \\
$\mathbf{1 1}$ & 13 & 10 & 11 \\
Ampicillin & & & \\
$100 \mu g(\mathrm{dw}) /$ disc & $\mathbf{2 4}$ & $\mathbf{1 9}$ & \\
\hline
\end{tabular}

‘ - ' No inhibition, ‘ * ' Moderate/ highest inhibition

Table 2. Antibacterial screenings (gram negative) of the test compounds.

\begin{tabular}{|c|c|c|c|}
\hline \multirow{2}{*}{$\begin{array}{l}\text { Compound } \\
\text { No. }\end{array}$} & \multicolumn{3}{|c|}{ Diameter of zone of inhibition in mm $(100 \mu \mathrm{g}(\mathrm{dw}) / \mathrm{disc})$} \\
\hline & $\begin{array}{c}\text { Shigella } \\
\text { dysenteriae }\end{array}$ & Salmonela typhi & Pseudomonous sp. \\
\hline 2 & 6 & - & - \\
\hline 3 & - & 7 & 10 \\
\hline 4 & 11 & 8 & 9 \\
\hline 5 & $29 *$ & $22 *$ & $18^{*}$ \\
\hline 6 & $35^{*}$ & $25^{*}$ & 13 \\
\hline 7 & 25 & 16 & 11 \\
\hline 8 & 22 & 20 & $16^{*}$ \\
\hline 9 & 19 & 12 & 10 \\
\hline 10 & $26^{*}$ & $21^{*}$ & 12 \\
\hline 11 & 20 & 17 & 9 \\
\hline $\begin{array}{c}\text { Ampicillin } \\
100 \mu g(d w) / d i s c\end{array}$ & 30 & 24 & 15 \\
\hline
\end{tabular}


Table 3. Inhibitory activity of different synthesized compounds (2-11) against various fungi.

\begin{tabular}{cccccc}
\hline \multirow{2}{*}{$\begin{array}{c}\text { Compd. } \\
\text { No. }\end{array}$} & \multicolumn{4}{c}{ Percent (\%) Inhibitions of mycelial growth $(100 \mu \mathrm{g}(\mathrm{dw}) / \mathrm{ml}$ PDA) } \\
\cline { 2 - 6 } & $\begin{array}{c}\text { Macrophomin } \\
\text { a phaseolina }\end{array}$ & $\begin{array}{c}\text { Fusarium } \\
\text { equiseti }\end{array}$ & $\begin{array}{c}\text { Alternaria } \\
\text { alternata }\end{array}$ & $\begin{array}{c}\text { Colletotrichu } \\
\text { m corchori }\end{array}$ & $\begin{array}{c}\text { Curvularia } \\
\text { lunata }\end{array}$ \\
\hline $\mathbf{2}$ & 26 & 12 & 23 & 16 & 57 \\
$\mathbf{3}$ & 17 & 31 & 20 & 21 & 50 \\
$\mathbf{4}$ & 24 & 21 & 29 & 13 & 28 \\
$\mathbf{5}$ & $72^{*}$ & $43^{*}$ & $55^{*}$ & $42^{*}$ & $77^{*}$ \\
$\mathbf{6}$ & $70^{*}$ & $47^{*}$ & $60^{*}$ & $40^{*}$ & $74^{*}$ \\
$\mathbf{7}$ & 37 & 22 & 41 & 33 & 46 \\
$\mathbf{8}$ & 40 & 25 & 39 & 17 & 56 \\
$\mathbf{9}$ & 50 & $44^{*}$ & 35 & 25 & $67^{*}$ \\
$\mathbf{1 0}$ & $62 *$ & 32 & 40 & 32 & $65^{*}$ \\
$\mathbf{1 1}$ & 53 & $\mathbf{4 5 *}$ & 26 & 21 & 55 \\
Nystatin & & & & & \\
$100 \mu g$ & $\mathbf{7 1 . 7 8}$ & $\mathbf{4 4 . 7 0}$ & $\mathbf{5 1 . 5 5}$ & $\mathbf{4 0 . 5 1}$ & $\mathbf{7 5 . 0 0}$ \\
(dw)/PDA & & & & & \\
\hline
\end{tabular}

' - ’ No inhibition, ‘ *' Moderate/ highest inhibition.

\section{Results and Discussion}

When 2-amino-4,5-dimethylthiophene-3-carbonitrile 1 was prepared by usual Gewald procedure [28], it was refluxed with formic acid for cyclization to form thienopyrimidinone 2, which was confirmed by ${ }^{1} \mathrm{H}-\mathrm{NMR}$ and ${ }^{13} \mathrm{C}-\mathrm{NMR}$ spectra. The thienopyrimidinone 2 was then chlorinated with thionyl chloride to form 4-chloro-5,6dimethylthieno[2,3-d]pyrimidine 3. Hydrazinopyrimidine $\mathbf{4}$ was obtained upon treatment of chloro derivative $\mathbf{3}$ with hydrazine hydrate in dioxane under reflux condition. Hydrazonopyrimidine $\mathbf{4}$ was then readily cyclized to the corresponding two cyclized compounds, 8,9-dimethyl[1,2,4]triazolo[4,3-c]thieno[3,2-e]pyrimidine 5, 3,8,9-trimethyl [1,2,4]-triazolo[4,3-c]thieno[3,2-e]pyrimidine 6 with formic acid and acetic anhydride, respectively. The ${ }^{1} \mathrm{H}-\mathrm{NMR}$ spectrum of 5 exhibited one-proton singlets at $\delta 7.90$ for 5$\mathrm{CH}$ proton and $\delta 8.50$ for 3-CH proton and the disappearance of $\mathrm{NH}$ and $\mathrm{NH}_{2}$ peaks clearly demonstrated the existence of molecule 5. Similarly the spectral data proved the formation of thieno[3,2-e]pyrimidine 6.

Synthesis of some Thienopyrimidines from o-Aminonitrile (5-11) shown in scheme 1. 


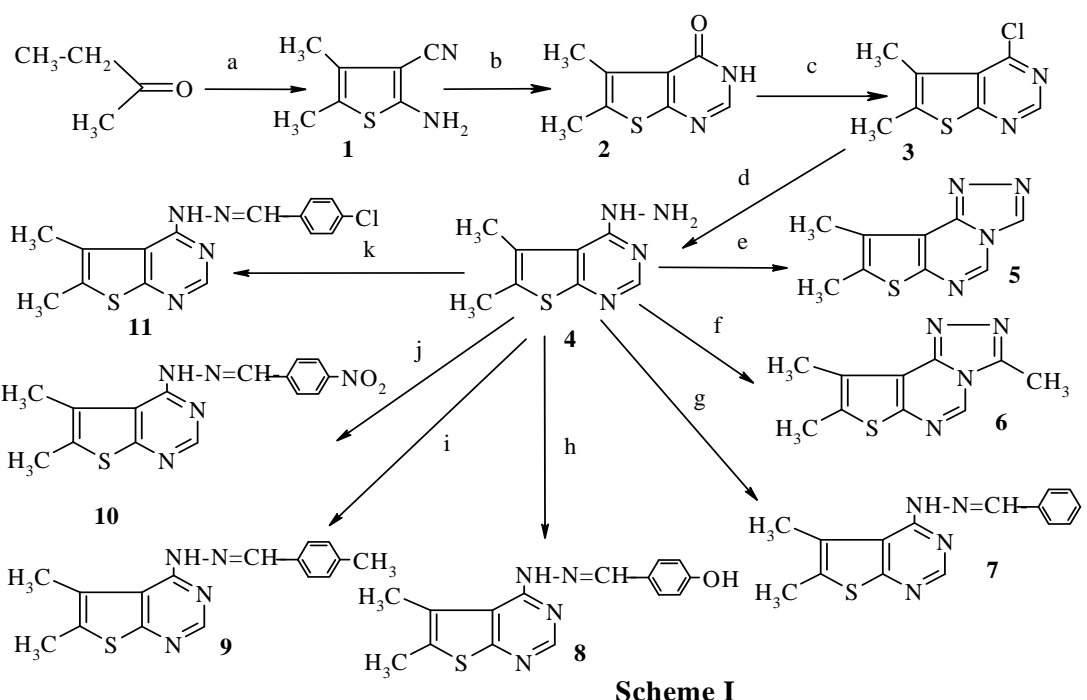

\section{Reagents}

a) Malononitrile, $\mathrm{S}, \mathrm{Et}_{2} \mathrm{NH}, \mathrm{EtOH}$, b) $\mathrm{HCOOH}$, reflux, $110^{\circ} \mathrm{C}, 4$ hours, c) $\mathrm{SOCl}_{2}$, reflux, 4 hours, d) $\mathrm{NH}_{2}-\mathrm{NH}_{2} \cdot \mathrm{H}_{2} \mathrm{O}$, reflux, 1 hour, e) Formic acid, reflux, 2 hours, f) Acetic anhydride, reflux, 3 hours, g) Benzaldehyde, ethanol, reflux, 2 hours, h) p-Hydroxybenzaldehyde, ethanol, reflux, 3 hours, i) pTolualdehyde, ethanol, reflux, 3 hours, j) p-Nitrobenzaldehyde, ethanol, reflux, 3 hours, k) p-Chlorobenzaldehyde, ethanol, reflux, 4 hours.

Compound 4 also condensed to 4-benzylidinehydrazono-5,6-dimethyl-thieno[2,3-d] pyrimidine 7, 4-[4'-hydroxybenzylidine]hydrazono-5,6-dimethylthieno[2,3-d]pyrimidine 8, 4-[4'-tolylidin]hydrazono-5,6-dimethylthieno[2,3-d]pyrimidine 9, 4-[4'-nitrobenzylidine]hydrazono-5-ethyl-6-methylthieno[2,3-d]pyrimidine $\mathbf{1 0}$ and 4-[4'-chlorobenzylidine]hydrazono-5-ethyl-6-methylthieno[2,3-d]pyrimidine $\mathbf{1 1}$ upon treatment with benzaldehyde, $p$-hydroxybenzaldehyde, $p$-tolualdehyde, $p$-nitrobenzaldehyde and $p$ chlorobenzaldehyde respectively. ${ }^{1} \mathrm{H}-\mathrm{NMR}$ spectrum showed the appearance of one proton singlet for benzylic proton at $\delta 8.60$ and disappearance of $-\mathrm{NH}_{2}$ peak indicated the formation of Hydrazonothienopyrimidine 7 and its ${ }^{13} \mathrm{C}-\mathrm{NMR}$ spectra displayed signals at $\delta 154.7$ for benzylic carbon and $\delta 128.8$ as multiplet for phenyl group. The rest of the spectrum also in good agreement with the structure 7. Similarly, the corresponding thieno[2,3-d]pyrimidines 8-11 were ascertained by their spectral data (see experiment).

\section{Antimicrobial activity}

The inhibition zone of the micro-organisms due to the treatment of different synthesized compounds are mentioned in Tables 1 to 3 . It was found that the inhibition zone of the 
compounds 5, $\mathbf{6}$ and $\mathbf{1 0}$ were more effective than that of other chemicals for all bacterial strain. They exhibited stronger activity than ampicillin also towards Bacillus Subtilis and Shigella dysenteriae. Other compounds were either inactive or moderately to fairly active against the tested bacterial strain.

As far as antifungal activity is concerned, all compounds showed good to excellent activity against all the fungi. Especially, it could be stressed that the test chamicals $\mathbf{5}$ and $\mathbf{6}$ exhibited even stronger activity than nystatin against Macrophomina phaseolina and Alternaria alternata. From the observation of inhibitions of the tested compounds, it was ascertained that, generally triazolothienopyrimidine derivatives 5-6 exhibited higher activities against human pathogenic bacteria and phytopathogenic fungi.

\section{Conclusion}

In this work, we have demonstrated that cyclisation with pyrimidine ring from $o$ aminonitirile afforded thienopyrimidines and furopyrimidines with promising antibacterial and antifungal activity. The activity data obtained during the study will be certainly useful to go for further research for drug designing and synthesizing new fused pyrimidines.

\section{Acknowledgements}

The authors wish to thank Chittagong University Research Cell for providing financial assistance to carry out this research and Mr. M. K. Hossain for helping with the spectral data when he was in Japan as doctoral research fellow.

\section{References}

1. B. Okcelik, S. Unlu, E. Banoglu, E. Kupeli, E. Yesilada, and M. F. Sahin, Arch. Pharm. Pharm. Med. Chem. 336, 406 (2003). doi:10.1002/ardp.200300778

2. D. S. Dogruer, M. F. Sahin, E. Kupeli, and E. Yesilada, Turk, J. Chem. 27, 727 (2003).

3. E. B. Frolov, F. J. Lakner, A.V. Khvat, A. V. Ivachtchenko, Tetrahedron Lett. 45, 4693 (2004). doi:10.1016/j.tetlet.2004.04.093

4. E. Banoglu, C. Akoglu, S. Unlu, E. Kupeli, E. Yesilada, and M. F. Sahin, Arch. Pharm. Pharm. Med. Chem. 337, 7 (2004). doi:10.1002/ardp.200200738

5. M. Gokce, D. Dogruer, and F. Sahin, Il Farmaco 56, 233 (2001). doi:10.1016/S0014-827X(01)01037-0

6. G. Daidone, B. Maggio, D. Raffa, S. Plescia, M. L. Bajardi, A. Caruso, V. M. C. Cuttuli, and M. Amico-Roxas, Eur. J. Med. Chem. 29, 707 (1994). doi:10.1016/0223-5234(94)90033-7

7. A. A. Bckhit and M. A. Khalil, Pharmazie 53, 539 (1998).

8. R. Agarwal, C. Singli, and N. S. Mishara, Ind. Drugs 25, 185 (1988).

9. G. H. Sayed, M. A. Sayed, M. R. Mahmoud, and S. S. Shaaban, Egypt. J. Chem. 45, 767 (2002).

10. A. Katrusiak and S. Baloniak, Tetrahedron, 50, 12933 (1994). doi:10.1016/S0040-4020(01)81212-6

11. M. Shyimad, R. Kalsi, K. S. Dixit, and J. P. Barthwal, Arzneim-Fosch. Drug Res. 41, 514 (1991).

12. K. M. Shakhidoyator, E. O. Eripor, L. M. Yun, M. Y. Yamankulov, and Kadyrov, Chem. Abstr. 94, 192253 (1981). 
13. A. Coelho, E. Sotelo, N. Fraiz, M. Yanez, R. Laguna, E. Cano, and E. Ravina, , Bioorg. Med. Chem. Lett. 14, 321 (2004). doi:10.1016/j.bmcl.2003.11.009

14. E. Sotelo, N. B. Centeno, J. Rodrigo, and E. Ravina, Tetrahedron Lett., 58, 2389 (2002).

15. E. Sotelo, N. Fraiz, M. Yanez, V. Terrades, R. Laguna, E. Cano, and E. Ravina, Bioorg. Med. Chem. 10, 2873 (2002). doi:10.1016/S0968-0896(02)00146-3

16. J. Fetter, T. Czuppon, G. Hornyak, and A. Feller, Tetrahedron 47, 9393 (1991). doi:10.1016/S0040-4020(01)80886-3

17. V.J. Ram, Arch. Pharm. (Weinheim) 323, 895 (1990). doi:10.1002/ardp.19903231103

18. R.E. Howells, J. Tinsley, E. Devaney, and G. Smith, Acta Tropica 38, 289 (1981).

19. A. A. Elagamey, I. Elsaka, Z. E. Kandeel, and M. H. Elnagdi, Arch. Pharm. 317(s), 208 (1984).

20. M. A. Zahran, A. A. Hassanein, H. A. Esman, and Y. A. Ammor, Croatica Chem. Acta 70, 1039 (1997).

21. Z. E. Kandeel, A. M. Farag, A. M. Negm, A. K. Khalafalla, M. A. Raslan, and M. H. Elnagdi, J. Chem. Res. 416(M), 2332 (1994).

22. Z. E. Kandeel, E. A. Hafez, A. M. Sleim, F. M. Abdelatif, and M. H. Elnagdi, Heteroatom. Chem. 6, 305 (1995). doi:10.1002/hc.520060405

23. A. E. Farag, K. M. H. Dawood, and Z. E. Kandeel, J. Chem. Res. 8, 29 (1998).

24. A. A. Hussein, A. A. Alalla, T. S. A. Hafiz, and M. H. Elnagdi, J. Heteroatom Chem. 4, 93 (1997).

25. M. M. H. Bhuiyan, K. M. M. Rahman, M. K. Hossain, and M. I. Hossain, Croatia Chemica Acta, 78 (4), 633 (2005).

26. M. M. H. Bhuiyan, K. M. M. Rahman, M. I. Hossain, M. A. Naser, W. Summi, Journal of Applied Sciences Research 1 (2), 218 (2005).

27. M. M. H. Bhuiyan, K. M. M. Rahman, M. K. Hossain, M. A. Rahim, M. I. Hossain, and M. A. Naser, Acta Pharmaceutica 56, 441 (2006).

28. K. Gewald, E. Schinke, and H. Bottcher, Chem. Ber. 99, 94 (1966). doi:10.1002/cber.19660990116

29. M. Z. A. Badr, A. A. Geies, M. S. Abbady, and A. A. Dahy, Can. J. Chem. 76, 469 (1998). doi:10.1139/cjc-76-4-469

30. E. M. E. Fatma, A. S. A. Hanan, and M. A. Hassan, Molecules 11, 498 (2006). doi:10.3390/11070498

31. A. W. Bauer, W. M. M. Kirby, J. C. Sherris, and M. Turck, Am. J. Clin. Path. 45, 493 (1966).

32. R. K. Grover and J. D. Moore, Phytopathology 52, 876 (1962). 